cation use Barron's Profiles of American Colleges, which identifies roughly 200 to 250 colleges as 'very competitive' or 'most competitive', as a guide (cf. Leonhardt 2013); this means that between 4.5 and 5.5 percent of colleges are classified as 'elite'. A similar case can be made for the influence wielded by high schools. Douthat writes:

There are 31,700 high schools, public and private, nationwide, but only 930-roughly 3 percent—could claim more than four students in their 19982001 graduating classes who matriculated at Yale, Harvard, or Princeton. And Worth's top hundred sent a total of 3,452 kids to the big three during that time, meaning that roughly 22 percent of the 'Yarvton' student bodies emerged from fewer than 0.3 percent of America's high schools. (50)

The media coverage, the number of fictional accounts, and the general visibility and discursive leverage these highly selective institutions hold seem to suggest that every other American teen attends an elite school, and they create an image of the student at an elite institution as 'the' generic college student, which makes actual facts-for instance that "more than 40 percent of all undergraduates in this country are over the age of twenty-four, and close to 40 percent study part-time" (Bok 16)-seem surprising. Thus, there is an obvious and important imbalance whose cultural and socio-political implications will be discussed in a later section of this study.

\title{
4. 'Excellence and Equity': Merit as the Price of Admission
}

In addition to and continuously in dialogue with eliteness, merit is the second central trope around which the epistemology of elite education revolves. For the past few decades, it has been at the heart of most debates surrounding the elite educational space and its socio-cultural and political implications; Karabel even proposes that the entire "history of admissions at the Big Three has [...] been, fundamentally, a history of recurrent struggles over the meaning of 'merit"' (5). In this section, I share some general observations on the role of merit in the context of elite education, and discuss the history and current discursive role of the notion of a 'meritocracy'. 


\section{'Fundamentally Derivative': The Concept of Merit}

Among the most interesting qualities of 'merit' is that it is recognized as the admissions criterion on which almost everyone can agree. In part, this is probably due to another interesting quality, namely that despite—or rather because of?-its widespread usage, there is little agreement as to what it actually means. Philosopher Amartya Sen thus aptly begins his exploration of merit and justice by noting that the "idea of meritocracy may have many virtues, but clarity is not one of them" (5). According to Sen, the concept of merit is "fundamentally derivative, and thus cannot but be qualified and contingent" (ibid.). The Oxford English Dictionary defines merit as "the quality of deserving well, or of being entitled to reward or gratitude" or to a "claim or title to commendation or esteem; excellence, worth" ("merit"). Much like 'elite', then, merit is a relative term, characterized by elusiveness and semantic openness. Its definition depends on what societies or institutions at any given point in time hold to be valuable or worthy of support-or claim to. In the educational context, however, there is no agreement as to the relative weight and importance of, for instance, academic performance (as measured by grades and test results) vis-à-vis extracurricular activities, athletics, or social connections with a school.

If we believe media portrayals of students at elite institutions, they embody the perfect blend of all these qualities. Consider, for example, David Brooks's description of such "mentor magnets" in his book Bobos in Paradise: The New Upper Class and How They Got There (2000):

These are the kids who spent the crucial years between ages 16 and 24 winning the approval of their elders. Others may have been rebelling at that age or feeling alienated or just basically exploring their baser natures. But the people who made it to this page [the New York Times wedding page] controlled their hormonal urges and spent their adolescence impressing teachers, preparing for the next debate tournament, committing themselves to hours of extracurricular and volunteer work, and doing everything else we as a society want teenagers to do. The admissions officer deep down in all of us wants to reward these mentor magnets with bright futures, and the real admissions officers did, accepting them into the right colleges and graduate schools and thus turbocharging them into adulthood. (2000: 15)

Note that in this narrative, the students themselves hold all the agency. There is in this account no awareness of structural factors, such as the students' so- 
cio-economic background, their parents' influence, the role of different forms of capital and access to specific resources, etc. The topos of merit often offers ready-made answers to the questions prompted by the existence of elite educational institutions: How and why do individuals gain access to this exclusive and exclusionary space? They do so on the basis of merit, an unspecified mélange of innate abilities and individual achievement. What do they do once they have arrived at the elite campus? They further cultivate their meritoriousness by excelling in a number of academic, extracurricular, and athletic endeavors. A recent edition of Harvard Magazine puts it as follows:

There's a wide consensus that today's undergraduates make up the most talented, accomplished group of polymaths every assembled in Harvard Yard: there's nothing surprising about meeting a first-year cellist in the HarvardRadcliffe Orchestra who is also a formidable racer for the cycling club, or a student doing original research on interstellar dark matter who organized a relief effort in sub-Saharan Africa. (Lambert)

What do the meritocrats bring into the outside world once they leave the confines of the elite educational space? A unique blend of knowledge, skills, and leadership qualities - an evolved kind of merit - that authenticates and legitimates their future positions as society's leaders. Douthat aptly sums up the discursive function of the topos of merit: "So it is that at Harvard, and at similar schools around the country, a privileged class of talented students sit atop the world, flush with pride in their own accomplishments, secure in the knowledge that they rule because they deserve to rule, because they are the best" (12, emphasis in the original). Khan refers to the same phenomenon when he describes the "language of hard work" (55) that permeates the selfdescriptions of elite students and serves as "the linchpin to validating contemporary elite life: [the students'] abilities explain their achievements and their achievements thus justify their elite position" (2011: 178). Institutions themselves similarly utilize the topos of merit when they describe their student bodies as exceptionally ambitious, gifted, driven, and passionate. To further authenticate this narrative, student profiles on institutional websites often include stories of hardships overcome or professional successes celebrated. A majority of fictional accounts of the elite educational experience likewise center around the topos of merit, but shift the focus to the scholarship student who arrives at the elite institution to which he or she gained access on the basis of hard work and ambition. 
The topos of merit was not always articulated in the fashion exemplified by Brooks and Douthat. Reflecting on the changing interpretations of merit, Karabel argues that "beneath the flux has been a consistent pattern: the meaning of merit has shifted in response to changing power relations among groups as well as changes in the broader society" (5). He identifies a number of critical junctures in the conceptualization of merit: In the late nineteenth and early twentieth centuries, merit was ostensibly a purely academic category. Entrance exams administered by colleges and universities measured the prospective candidates' knowledge of a specific curriculum, including, importantly, Latin and Greek. Social exclusivity was guaranteed by the fact that most public high schools did not teach classical languages, thus effectively ousting their students from the competition. During the 1920s, however, as part of a conscious attempt to regain control over the composition of entering classes and limiting the number of 'undesirable' students, the notion of 'character' was introduced into the admissions politics of elite colleges. The gatekeepers now explicitly focused on "the idea of the 'all-round man' of sturdy character, sound body, and proper social background," as Karabel puts it (4). Athletic prowess and engagement in other extracurricular activities assumed primary importance over academic factors. In the 1950s, the Cold War, the reverberations of the Sputnik crisis, and the general American anxiety over competing with the Soviet Union gradually began to displace the ideal of the 'all-round man'; the so-called Gentleman's $C$ was no longer sufficient. Instead, the ideal of the 'exceptional student', gifted intellectually and otherwise, gained currency, and at the same time, the professionalization of mass intelligence testing promised to provide a means of identifying and selecting those students. Elite colleges and universities were expected to produce future leaders and scientists who would ensure America's global dominance. The 1960 s and 70s, by contrast, saw another shift in the definition of merit, as notions of 'diversity' and 'inclusion' began to enter the vocabulary of admissions officers. Since then, merit has stabilized as a heterogeneous category that on the one hand includes academic and extracurricular qualifications, and on the other refers to certain cultural, racial, or ethnic subject positions. As most elite campuses opened their gates to women and minorities, the WASP-y homogeneity of Dink Stover's campus slowly but steadily became a thing of the past-or so the story goes.

Today the meaning of merit is still widely contested. Though surveys indicate that most people understand merit in the educational context as an academic category (Soares 1), schools and colleges still adhere to a much broader 
conception, taking into account extracurricular activities, athletic prowess, ties to the institution, and potential financial expressions of gratitude. It is not surprising, then, that the discourse of elite education in general remains relatively vague on the issue. The meaning of merit becomes somewhat clearer when one focuses on the qualities that it is set against: the "accidents of birth" (Soares 2), "social ties and status" (Khan 2011: 9), or "inherited privilege" (Karabel 3)—qualities often evoked as ghostly and embarrassing relics of the past. Most discursive positions seem to agree that merit is not hereditary and cannot be bought or sold. Importantly, the fundamental implication of adopting merit as a guiding criterion for selection is that it is both possible and desirable to evaluate an individual "separate from the conditions of social life," as Khan puts it (2011: 9). Since this is, in fact, rather difficult to do, the admissions practices of elite institutions are still characterized by what Karabel calls discretion and opacity- "discretion so that gatekeepers would be free to do what they wished and opacity so that how they used their discretion would not be subject to public scrutiny" (2). Oscillating somewhat uneasily between aptitude and ambition, merit remains a problematic quality, and the fact that it seems somehow in larger supply with the children of privileged families continues to provoke critical interrogation.

\section{The Ideal of the Meritocracy}

Perhaps the most telling indicator of America's infatuation with the notion of merit is the enthusiastic appropriation of the notion of the 'meritocracy' as an ideal and guiding principle. As Christopher Hayes points out in Twilight of the Elites: America After Meritocracy (2012), "to call an organization, a business, or an institution 'meritocratic' is to pay it a high compliment" (31). This is significant in so far as British sociologist Michael Young originally coined the term in his satire The Rise of the Meritocracy (1958) to express criticism, not approval. Young's book takes the form of a fictional $\mathrm{Ph}$. D. thesis written in the year 2034, tracing the ascendancy of a new ruling class chosen exclusively on the basis of a series of valid and reliable tests of intelligence and aptitude. The fictional scholar himself puts it as follows: "Today we frankly realize that democracy can be no more than aspiration, and have rule not so much by the people as by the cleverest people; not an aristocracy of birth, nor a plutocracy of wealth, but a true meritocracy of talent" (Young 2011 (1958): 11). One of the results of the restructured class system is a steady loss of influence for the working class. On the one hand, this is due to the loss of ideological fervor 
since there is no longer an unfair class system against which to rebel-social stratification still exists, but it is ostensibly justified and fair. On the other hand, the working class loses its potential leaders as they are coopted by the meritocracy structures allowing them to rise above their station. The meritocracy itself, due to intermarriage, congeals into caste-like structures and thus increasingly starts to resemble a closed aristocracy, albeit a 'deserving' and efficient one. Young's main argument, curiously missed by most of his readers, is that the seemingly fair process of mass intelligence testing would ultimately produce rampant social inequality and erode all sense of solidarity among the citizenry.

Though Young had intended his study to be a cautionary tale, the term 'meritocracy' was adopted widely and uncritically as a synonym for fairness, and now lends an aura of legitimacy to all kinds of selection processes. Shortly before his death in 2002, Young himself, exasperated by the misunderstanding, commented on the term's popularity:

I have been sadly disappointed by my 1958 book, The Rise of the Meritocracy. I coined a word which has gone into general circulation, especially in the United States, and most recently found a prominent place in the speeches of Mr. Blair. The book was a satire meant to be a warning (which needless to say has not been heeded) against what might happen to Britain between 1958 and the imagined final revolt in 2033. (Young 2001)

Apart from the general discrepancy in evaluating the socio-political reverberations of meritocratic structures, it is interesting to note another difference between Young's usage of 'meritocracy' and that of public discourse: In Young's mock dissertation, the term meritocracy refers to the new meritocratic elite, the ruling class chosen on the basis of innate ability rather than inherited privilege. In contemporary (American) parlance, by contrast, the term is used to describe the system as such, not a specific group within that system. One explanation for this diverging use might be that labeling distinct social classes, whatever their legitimacy, does not resonate well with the American public since it indicates a certain affinity with other, less legitimate forms of rule, such as aristocracy or plutocracy.

As Young observes, the term 'meritocracy' is used widely and in many different contexts. Books such as Hayes's Twilight of the Elites or Stephen McNamee and Robert K. Miller Jr.'s The Meritocracy Myth (2009) take as their basis a rather broad understanding of meritocracy and thus consider a whole array of key sectors across American society, but the term is also used on a smaller 
scale. One example cited by Hayes is the investment banking firm Goldman Sachs, which claims to be "a meritocracy built on the belief that collaboration, teamwork and integrity create the right environment for our people to deliver the best possible results for our clients" ("Why Goldman Sachs"; cf. Hayes 31). The original context of the concept, however, was education, and conceived of merit as a value "assessed by a competitive educational system" ("meritocracy"). Today, despite its wide semantic range and eclectic usage, the notion of the meritocracy is still closely tied to the educational system and specifically to the elite educational system.

There are several reasons for this connection. In Young's original account, the meritocracy was selected via educational institutions, which offer the greatest variety of those instruments needed as the prerequisites for a functioning meritocracy: systematic examinations, reliable and valid mass testing, in-depth reviews conducted by ostensibly neutral agents. Another reason for the link between the meritocracy and education lies in the fact that the campus is often seen as a microcosm of society (cf. Showalter 3). People live, work, and play on the campus; they form relationships; its infrastructure includes legislative, executive, and judicative dimensions; it is equipped with its own media landscape; it offers arts, sports, food, and entertainment-just like the 'real world'. If, in the words of Jay Parini, the campus is "a place where humanity plays out its obsessions and discovers what makes life bearable," then perhaps this accounts for the continued popularity of the campus as a setting for fictional and non-fictional narratives. Since the campus is often seen as a pars pro toto for society, it also frequently serves as a yardstick for measuring society's progress. This is true especially for the elite campus due to its heightened visibility, which then seems to suggest that the elite campus is an ideal microcosm of an ideal society.

The elite educational space is misconceived as the generic educational space, which in turn is seen as a mirror of society. The fact that Harvard is now welcoming its most diverse entering class ever into its ivied walls is turned into a source of comfort and pride to those who want to see a more just and egalitarian society. The more enthusiastic these accounts are, the more likely are they to forget that a meritocratic society "is not an expression of, but an alternative to, a more egalitarian society," as Karabel puts it (4). The meritocracy, after all, is not opposed to stratification per se, just to certain kinds of stratification. This line of reasoning furthermore neglects the exceptional status of the elite educational space. Just as Hillary Clinton's success as a female politician does not say much about the overall situation of women in politics, 
the racial, ethnic, and socio-economic makeup of the elite campus does not say much about anything except just that. It certainly does not say whether the American society works according to meritocratic principles, nor does it seriously engage with question of whether this would be a desirable goal in the first place.

Part of the elite campus's continuing allure is that it forms a crucial and unique part of the American cultural heritage-Harvard, for instance, was founded in 1636 - and even though the semiotics of elite education are somewhat at odds with other fundamentally American tropes, such as, for instance, the frontier, it forms a well-established part of the American cultural inventory. Films, television series, and novels are full of references to actual or fictional elite institutions. Sometimes these references are humorous, like 30 Rock's Jack Donaghy claiming that he was a recipient of the 'Amory Blaine Handsomeness Scholarship' at Princeton; sometimes they are used to establish a backstory; sometimes they are critical or disparaging. In any case, references to elite institutions occur frequently and in a variety of different contexts.

In its cultural work as a signifier, the elite educational space appropriates the legitimacy conferred by the topos of merit. In conjunction with the mechanisms of the pastoral and picturesque, a powerful image of legitimate privilege is created. The references to the elite educational space and the utilization of its aesthetics function as shorthand for a privileged life, a beautiful life, but most importantly: a legitimately privileged and beautiful life. They thus reflect Max Weber's observation about good fortune and legitimacy:

The fortunate is seldom satisfied with the fact of being fortunate. Beyond this, he needs to know that he has a right to his good fortune. He wants to be convinced that he 'deserves' it, and above all that he deserves it in comparison with others. He wishes to be allowed the belief that the less fortunate also merely experiences his due. Cood fortune thus wants to be 'legitimate' fortune. (quoted in Gerth and Mills 271)

This set of meanings associated with the elite educational space is utilized in non-educational contexts as well, for instance when fashion brands such as Polo Ralph Lauren, Tommy Hilfiger, or J.Crew appropriate its aesthetics to add an aura of legitimate superiority and elite distinction to their products.

The tenacity of the connection between the concept of meritocracy and the notion of legitimate privilege becomes obvious, moreover, in the lack of any genuine critique of meritocratic structures and in the inability or un- 
willingness, in the overall discourse of elite education, to suggest meaningful alternatives. As the second chapter of this study shows in greater detail, sociological studies and journalistic investigations of elite education all find fault with the status quo of the meritocracy, but simultaneously operate entirely within its ideological framework. Their suggestions for reform, then, are geared toward improving the meritocracy by making it more just and less susceptible to the undue influence of capital and power. There is very little awareness in this critical landscape of the systemic flaws and inconsistencies of the ideology of meritocracy-flaws and inconsistencies that were so obvious to Michael Young when he coined the term. A recent and paradigmatic case in point is Lani Guinier's book The Tyranny of the Meritocracy: Democratizing Higher Education in America (2015). Its title suggests an awareness of the pitfalls of meritocratic structures and a commitment to rethinking and reforming the educational system in accordance with democratic principles. Guinier's central suggestion, however, is simply to change the definition of merit from what she calls a 'testocratic' one-test scores, grades, and other measures of individual competition-to a 'democratic' one: "a student's capacity to collaborate and think creatively" (xiii). "If we are going to have a 'meritocracy'-which really just means 'rule by merit'," Guinier writes, "then we need a better conception of what now constitutes merit in our society versus what it should be" (xi). Despite the implications of its title, then, Guinier's book likewise operates squarely within the ideological framework of the meritocracy. There surely are in the United States educators, researchers, or other commentators who are genuinely critical of the very idea of the meritocracy and attempt to think of alternative systems instead of merely changing the definition of merit. In the discourse of elite education, however, these voices are not heard.

\section{5. 'A Touchy Subject'? Class and Elite Education}

As the previous sections have shown, eliteness is an elusive quality that the discourse of elite education does not always make explicit, even though it is at the heart of its epistemological practices. Merit, by contrast, is a concept with strong legitimatory potentials and, as such, is frequently invoked, despite the lack of agreement on its meaning(s). The constitution and operation of both notions, as has become clear time and again, depends strongly on different forms of capital. The production of meritorious-i.e. "measurably 